\title{
The biological, social, and political complexity of conserving oribi antelope Ourebia ourebi in South Africa
}

\author{
Adrienne J. Louw ${ }^{1, \#}$, Elizabeth F. Pienaar ${ }^{1,2, *, \#}$, Adrian M. Shrader ${ }^{1}$ \\ ${ }^{1}$ Mammal Research Institute, Department of Zoology \& Entomology, University of Pretoria, Private Bag X20, Hatfield 0028, \\ South Africa \\ ${ }^{2}$ Warnell School of Forestry and Natural Resources, University of Georgia, 180 E Green Street, Athens, GA 30602-2152, USA
}

\begin{abstract}
The endangered oribi antelope Ourebia ourebi is highly dependent on privately owned lands for its continued survival in South Africa. Despite the fact that conserving oribi may result in costs to farmers in the form of land use restrictions and pressures from illegal hunting, there is evidence that South African farmers are willing to conserve oribi on their lands. However, to date, no research has been conducted to examine farmers' understanding of how to manage their lands for oribi or their motivations for conserving this species. We conducted 50 in-depth interviews with private landowners in KwaZulu-Natal, South Africa, to investigate why farmers are willing to protect oribi, their perceptions of the threats to the species, and their understanding of how land should be managed to benefit oribi. Respondents' willingness to conserve oribi was driven primarily by an affinity for the species and wildlife in general. Respondents perceived illegal taxi hunting to be the greatest threat to oribi. Taxi hunts are organized, illegal hunting events that involve multiple participants and packs of dogs, who hunt at night on farms without the permission or knowledge of farmers. Although some respondents managed their lands specifically to benefit oribi, most were unsure which land management practices would support oribi conservation efforts. Farmers require legal support to more effectively conserve oribi. In addition, they would benefit from outreach and awareness programs on how to manage their lands for oribi.
\end{abstract}

KEY WORDS: Grassland conversion - KwaZulu-Natal - Illegal hunting - Qualitative analysis · Semi-structured interviews $\cdot$ Social conflict $\cdot$ Taxi hunting

\section{INTRODUCTION}

South Africa, like many countries, is largely dependent on state-owned protected areas to conserve biodiversity. Although at least $8 \%$ of the country is comprised of protected areas, the South African Department of Environment, Forestry, and Fisheries recognizes that the protected area network does not represent all ecosystems and falls short of maintaining biodiversity (Skowno et al. 2019). Much of South Africa's threatened habitat is privately owned, and many threatened and endangered species exist out-

*Corresponding author: elizabeth.pienaar@uga.edu

"These authors contributed equally to this work side publicly managed protected areas (Clements et al. 2019, Shumba et al. 2020). Private landowners thus play a critical conservation role. However, achieving the conservation of threatened and endangered species on private lands is challenging. Landowners bear the costs of conservation, both in terms of implementing conservation practices and the loss of potential income, whilst receiving little to no economic return unless they secure a tax reduction by enrolling in a biodiversity stewardship program (Lapeyre \& Laurans 2017) or they engage in wildlifebased economic activities such as wildlife ranching

(1) The authors 2021. Open Access under Creative Commons by Attribution Licence. Use, distribution and reproduction are unrestricted. Authors and original publication must be credited. 
(Taylor et al. 2020). Although landowners receive tax reductions for enrolling in biodiversity stewardship agreements, some of these agreements require land to be formally declared as protected areas under the Protected Areas Act (South African National Biodiversity Institute 2015), which places strict constraints on land use. Moreover, conservation of endangered species may result in high anti-poaching security costs or safety risks for landowners and their staff (Rubino \& Pienaar 2018).

Despite the costs associated with participating in conservation efforts, private landowners in South Africa have voluntarily engaged in conservation activities (e.g. through the creation of conservancies; De Vos et al. 2019). Landowners' willingness to engage in conservation may be motivated by both financial and non-financial considerations (Gooden \& Grenyer 2019). The Game Theft Act in South Africa permits private landowners to own wildlife on their land and to generate wildlife-based income (Taylor et al. 2020), which in turn has encouraged sustainable use of wildlife (Pienaar et al. 2017). Landowners may conserve species as part of their cultural heritage or because they are motivated by a moral obligation to protect the environment (Pradhananga et al. 2017). Landowners may also possess an emotional affinity for nature or a species that drives their desire to protect it (Rubino \& Pienaar 2018). Nonetheless, private lands remain at risk of conversion to land uses that are inconsistent with biodiversity conservation, such as residential or industrial development, and mining (De Vos et al. 2019, Clements et al. 2020). Habitat fragmentation and illegal hunting on private lands are placing increased pressure on multiple threatened and endangered species, including oribi antelope Ourebia ourebi.

Oribi antelope are South Africa's most endangered antelope species (Shrader et al. 2016, Manqele et al. 2018), although oribi are listed as Least Concern globally on the IUCN Red List because populations outside South Africa are relatively high in number. Oribi are a small $(7-17 \mathrm{~kg}$; Skinner \& Chimimba 2005) territorial antelope (Brashares \& Arcese 1999). They are ruminants that require short, highly palatable grass species that provide high-quality grazing, as well as longer grass species that provide food, refuge, and cover for the concealment of young (Stears \& Shrader 2015, Shrader et al. 2016). The grassland biome on which the species is dependent for survival is threatened, with only $2.4 \%$ of this biome in South Africa being conserved (Carbutt \& Martindale 2014). Accordingly, oribi in South Africa are heavily dependent on private lands for their con- tinued survival (Shrader et al. 2016, Manqele et al. 2018).

Oribi in South Africa have experienced severe reductions in both their distribution and population numbers, owing to conversion of the grassland habitat on which they rely, snaring, and illegal dog hunting (Shrader et al. 2016). The oribi's remaining habitat in South Africa is highly fragmented, with much of it in poor condition due to inappropriate grassland management practices (Shrader et al. 2016, Manqele et al. 2018). Illegal hunting of oribi in South Africa has resulted in the local extinction of subpopulations on private lands (Shrader et al. 2016). Most illegal hunting occurs in the form of dog hunting by local community members and taxi hunting (Shrader et al. 2016). Taxi hunts are organized hunting events. Although these hunts are sometimes facilitated by local community members, they are typically organized by criminal syndicates for individuals who do not reside in the local area. Taxi hunts involve multiple participants and packs of dogs (often greyhounds) arriving at farms at night, or in the early morning, in minibus taxis; the dogs are then released onto farms to hunt illegally without farmers' knowledge or permission. Participants then place bets on the outcome of the hunt (Grey-Ross et al. 2010), with particular focus on oribi kills, although dogs often hunt indiscriminately. Biologists consider taxi hunts to be more destructive to the oribi population than dog hunting by local communities for food and subsistence purposes (Shrader et al. 2016). Unfortunately, oribi run short distances and then they lie down and remain still when threatened, a predator response that makes them highly susceptible to hunting with dogs.

Although traditional hunting with paid permits is allowed in South Africa (Chambers 2020), both taxi hunting and hunting of oribi with dogs by local community members are prohibited by the Threatened or Protected Species (TOPS) regulations (enacted under the National Environmental Management: Biodiversity Act, Act 10 of 2004) because oribi are endangered. Taxi hunting also contravenes the Animals Protection Act (Act 71 of 1962, https://www.animal law.info/sites/default/files/AnimalsProtectionAct7162.pdf) of South Africa, which stipulates that 'Any person who ... liberates any animal in such manner or place as to expose it to immediate attack or danger of attack by other animals ... or incites any animals to attack any other animal ... shall be ... guilty of an offence and liable on conviction to a fine'. Because most commercial farmers in South Africa are white, and illegal hunting is predominantly conducted by 
black South Africans, illegal hunting of oribi exacerbates social and political tensions (Chambers 2020).

Interestingly, private landowners in South Africa voluntarily engage in oribi conservation efforts, despite the fact that this may result in illegal hunting threats and restrictions on land management activities. Most of South Africa's oribi population occurs on high-value agricultural land, and TOPS regulations may have negative economic consequences for farmers by restricting how they manage their land to prevent further degradation and fragmentation of oribi habitat. TOPS regulations and the Natal Nature Conservation Ordinance 15 of 1974 (which applies in KwaZulu-Natal [KZN], our study region) also require landowners to obtain permits from Ezemvelo KwaZulu-Natal Wildlife (the government agency responsible for managing wildlife) to hunt, sell, capture, or introduce oribi on their properties. Our research was designed to investigate why private landowners are willing to incur these costs to conserve a lesser-known antelope species. We investigated landowners' perceptions of the threats to oribi and how land should be managed to benefit the species to identify gaps between landowners' and biologists' understanding of oribi management.

\section{METHODS}

\subsection{Study area}

Oribi range on the grassland biome, which is found on the high central plateau of South Africa and the inland areas of KZN and the Eastern Cape. Most of the oribi's existing range is distributed across KZN and Mpumalanga provinces, but oribi are also found in the Eastern Cape, Free State, Gauteng, North West, and Limpopo provinces (IUCN SSC Antelope Specialist Group 2016). In South Africa, $75 \%$ of the extant oribi population exists on privately owned land, with $45 \%$ of the population occurring in KZN (Shrader et al. 2016). Accordingly, we conducted our research in KZN. The most recent Land Audit showed that 853152 ha of agricultural land in KZN (53\% of total agricultural land) is owned by white South Africans, and 270423 ha (17\%) is owned by black South Africans (nationally, white individuals own $72 \%$ of agricultural land and black individuals own $4 \%$ of agricultural land; Rural Development \& Land Reform 2017). Only 4 of the 143 known farms with oribi are owned by black farmers $(2.3 \%$; Oribi Working Group unpubl. data). We invited farmers from regions differing with regards to oribi density to participate in this study (Fig. 1). Owing to funding and logistical constraints, we were unable to travel to the northern region of KZN to conduct interviews.

\subsection{Data collection and analysis}

We conducted in-depth interviews with farmers in KZN from October 2017 to May 2018. We interviewed farmers who currently or previously had oribi on their property, as well as those whose properties possessed suitable oribi habitat, but had never had oribi. We used qualitative research methods to allow for collection of more detailed, in-depth information on people's perspectives, thoughts, motivations, and actions than would be possible using quantitative research methods (Bryman 2001).

We used referral (snowball) sampling to select research participants because oribi conservation is a sensitive topic, requiring trust between the researcher and research participant (Kirchherr \& Charles 2018). Referral sampling relies on research participants to recruit or recommend new study participants. We obtained an initial contact list of 10 farmers with oribi on their properties from the Oribi Working Group, a committee that works to manage the oribi population, address threats to oribi conservation, and develop relationships with private landowners who have oribi present on their lands. At the end of each interview, we asked for the names of other individuals who we could contact to interview.

We conducted a total of 50 interviews (98\% response rate; 1 farmer declined to participate in the study). All interviews were conducted face-to-face. On average, interviews lasted $54 \mathrm{~min}$. We transcribed the interviews, and then 2 researchers independently analyzed the transcripts to identify key themes using open coding (Berg et al. 2004). To check for consistency in our results, we compared and discussed themes, prior to finalizing our findings (Berg et al. 2004). The study was approved by the ethics committee at the University of Pretoria (EC171106-158).

\section{RESULTS}

Research participants were white, aged between 30 and $79 \mathrm{yr}($ mean \pm SD: $55 \pm 12 \mathrm{yr}$ ) and were predominantly male $(\mathrm{n}=49 ; 98 \%)$ with a tertiary education level ( $\mathrm{n}=39 ; 78 \%$ ). Respondents' farms ranged from 23 to 9300 ha in size (1551 \pm 1842 ha), and 41 respondents (82\%) were multi-generational farmers. Respondents engaged in a variety of farming activi- 


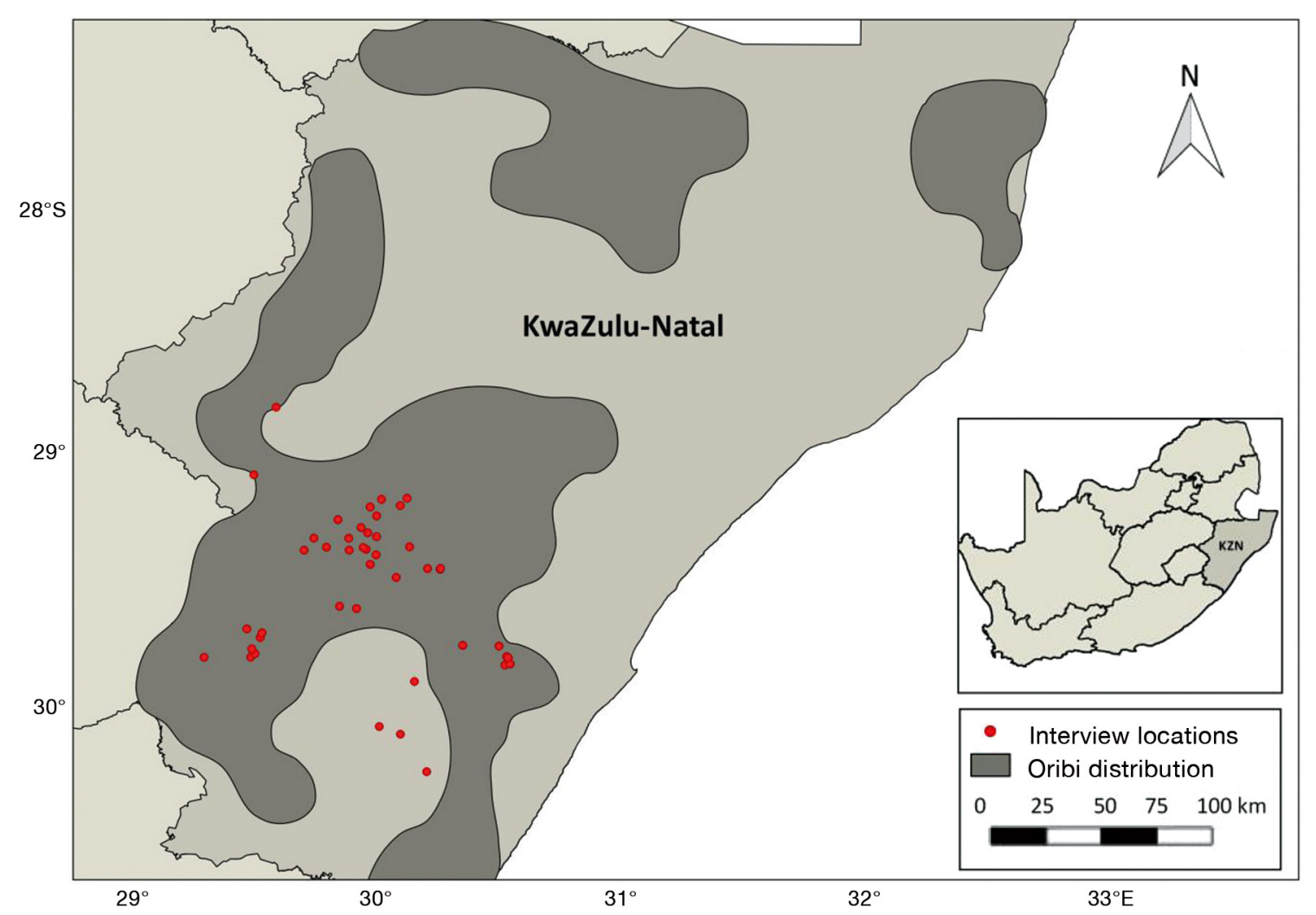

Fig. 1. Geographic distribution of research participants relative to distribution of oribi Ourebia ourebi in KwaZulu-Natal (inset: South Africa). Dark grey: estimated current distribution of oribi based on observed presence (i.e. recorded sightings) of oribi. Light grey: contains suitable habitat for oribi and is within its traditional range, but with no official sightings of oribi currently recorded

ties, including: beef $(\mathrm{n}=34 ; 68 \%)$, sheep $(\mathrm{n}=12$; $24 \%)$, and dairy production $(\mathrm{n}=14 ; 28 \%)$; hay $(\mathrm{n}=$ $31 ; 62 \%)$, crop $(\mathrm{n}=31 ; 62 \%)$, and sugar cane production $(\mathrm{n}=7 ; 14 \%)$; timber production $(\mathrm{n}=16 ; 32 \%)$; and game ranching $(\mathrm{n}=4 ; 8 \%)$. Most respondents engaged in $>1$ land use on their properties.

Forty-nine respondents (98\%) possessed natural grassland on their properties. Thirty-nine respondents $(78 \%)$ currently had oribi on their property (hereinafter, oribi owners), whilst 7 had oribi on their property in the past. Four respondents $(8 \%)$ had never had oribi on their properties. We included landowners who had never had oribi on their properties in our final sample because landowners without oribi on their land still have the potential to manage their land for oribi. These landowners provided insights into potential knowledge gaps about oribi management, as well as barriers and concerns that might preclude landowners actively encouraging the presence of oribi on their land. Oribi owners stated that they had between 2 and 45 oribi on their properties (10 \pm 9 oribi). Respondents with a larger number of oribi generally considered that they were at carry- ing capacity for oribi because the population on their farm had remained stable over time. Some respondents with smaller numbers of oribi on their farms were concerned that the population was not viable. Those who stated that the oribi on their property had been eradicated attributed this decline to drought, illegal hunting, and predators.

\subsection{Landowners' motivations for protecting oribi}

Respondents $(\mathrm{n}=34 ; 68 \%)$ protected oribi on their properties because of a love of wildlife and a belief that wildlife conservation is part of their farming and hunting heritage, and important for future generations. Nine respondents $(18 \%)$ expanded on this theme by stating that protecting wildlife is part of their larger heritage of environmental stewardship. Respondents also actively protected oribi on their farms because they have a strong emotional attachment to the species $(\mathrm{n}=12 ; 24 \%)$, the species is endangered $(\mathrm{n}=21 ; 42 \%)$, and the oribi is particularly vulnerable to illegal hunting ( $\mathrm{n}=21 ; 42 \%)$. 
Three examples of responses follow:

- 'Personally, I love oribi, but I think the reason I choose to be involved in protecting them is to maintain a viable population on the farm, which makes a valuable contribution to the long-term conservation of the species.'

- '[Protecting oribi] is my social responsibility ... They're critically endangered. They are so vulnerable. There are gangs of hunters who think it's funny to let loose a dozen greyhounds and hunt them down. I can't handle that. I just can't handle it. So, I will do whatever it takes to protect these animals.'

- 'One of the things that gets me out of bed in the mornings are the wild animals. The oribi are a joy for me to see.'

Respondents routinely characterized the oribi as a 'stupid' animal that is unable to defend itself against dogs, and thus requires protection to ensure its survival. Respondents spoke about the fact that the oribi often does not flee when chased by dogs, stating, for example, 'They're just stupid. They get up and run like hell and stop and look and then sit down. And that's deadly.' Finally, 3 respondents noted that the oribi is a financially valuable species, which can be sold to landowners in South Africa and Eswatini for ZAR 25 000-34 000 ( USD 1730-2350) per individual (if the appropriate permits are obtained). Although other respondents recognized that they could generate income from oribi, they elected to keep oribi on their farms out of emotional attachment to the species, rather than to generate revenues from selling live oribi.

\subsection{Managing the threat of snaring}

On the whole, respondents considered snaring to be a minimal threat to oribi. Thirty respondents $(60 \%)$ controlled for snaring by patrolling their fences and removing snares. Although 25 respondents $(50 \%)$ checked for snares regularly (at least once per month, typically on a weekly basis or during daily tasks), 5 respondents (10\%) only checked for snares occasionally (e.g. when burning fire breaks). Those respondents who regularly checked their fences for snares typically tasked their employees with removing snares and reporting any signs of snaring, noting, for example:

- 'Checking for snares is a constant thing. We walk around the farm a lot. And our herders are instructed to let us know if they find any [snares].'

- 'We have game guards that patrol. My farm is patrolled twice a month. So, with a game guard you're never going to stamp out a problem, but you're going to put a measure of control on it.'

Although local communities may set snares to catch wildlife for food, respondents stated that, in most cases, it is farm employees who set snares because they know where snares are most likely to trap wildlife (for food consumption). Respondents typically dealt with snaring by their employees by monitoring and fining or firing any employees who snared or illegally hunted wildlife. Respondents stated the effectiveness of these measures depended on a consistent response to snaring or illegal hunting and the continued presence of the farm owner or manager on the property, as, for example, 'I think snaring tends to be a dual thing. One thing is if the landowner or land custodian is aware of it or not. Is it something they think is important or not? I think the other thing is that you will often find 1 individual who works on the farm is a problem, as opposed to being everybody.' Respondents stated that although snaring would likely continue, its severity would decrease if the livelihoods of local community members improved and they were better able to afford food.

\subsection{Dog hunting by local communities}

Respondents stated that if a farm is located close to a local community, then the probability that community members will illegally hunt wildlife on the farm using dogs increases. Moreover, unsupervised dogs will roam onto farms and kill wildlife. According to respondents, local community members typically target animals for meat, but unsupervised dogs kill indiscriminately. Respondents noted that conflict about illegal hunting arises because communities consider killing livestock to be livestock theft but killing wildlife to be traditional hunting.

On average, respondents considered this form of illegal hunting to be a moderate, rather than a serious, threat to wildlife. Respondents stated that communities hunt for subsistence purposes, the hunters are not armed, and wildlife have a 'fighting chance' of escaping dogs. Respondents who took efforts to prevent dog hunting on their property warned hunters to leave their properties and not hunt on their farms again, placed security guards at strategic points on the farm where stock theft or illegal hunting is known to occur, or shot and poisoned dogs. Two examples are given in the following:

- 'Local communities would rather I turned a blind eye to their poaching activities. But I [intervene] in as humanistic a way as possible. I don't go in there as 
the [big white boss] screaming, and shouting, and kicking. I go in and I say 'hey guys, I'm going to shoot your dogs. If I catch them hunting on my property, I am going to shoot them. Please, please. My heart hurts. Don't make me shoot them'.'

- 'We've destroyed [dogs] on this property and then in the area. We have to. Unaccompanied, unhandled, stray - those are the dogs that are destroyed without question. It's just done.'

Respondents who destroyed dogs ( $\mathrm{n}=32 ; 64 \%$ ) recognized that killing dogs exacerbates racial and social tensions between local communities and farmers and may result in retaliation by community members (e.g. arson on the farm). Respondents also stated that by law they may not apprehend any hunter on their land unless they catch that individual hunting, and they may not shoot dogs that are accompanied by a handler. Nonetheless, some respondents were determined to establish a reputation for shooting dogs to deter illegal hunting on their properties, stating, for example, 'I think over a 12 or $15 \mathrm{yr}$ period we probably shot 1000 dogs. It was very effective. And the first time we shot dogs there was a huge uproar from the community and [the state wildlife agency explained to the community that] when you've got a dog with you, the dog has to be under control. It must be on a lead. If the dog is not on a lead, it is considered a free-roaming animal. When the owners of the dog tried to charge us for shooting their dogs, it was thrown out by the magistrate because of the law. As a result of that, it opened the door for our game guards to control those dogs ... So, the traditional hunting and snaring we estimate was reduced by about $90 \%$.'

Two respondents had taken a different approach by engaging in talks with the local community. They had spent time building trust with the community and earning their respect, although they had been subsequently ostracized by the farming community for taking this approach. These individuals argued that it is hypocritical for white farmers to hunt on their lands throughout the year, to hunt more animals than the number of permits issued, to ask their staff to clean the carcasses, and then to condemn dog hunters. However, these respondents also noted that local communities use dog hunting as a political weapon against farmers, with one respondent explaining, 'How do you put pressure on a guy if you don't want him there? You give him trouble by hunting ... The hunters have become very legally knowledgeable. They know what they can get away with and what the farmers can't get away with. So, it's like a massive challenge. It's like they see it as a competi- tion as to which of them can press the most buttons and cause the most trouble. How we've always treated hunting is that you must be very careful because it's politically driven and we've always dealt with the community and followed [the hunters] back to their houses and identified them. We've done it a different way so we've actually earned their respect because they know they can trust us.'

Some respondents were considering altering the fences along property lines that are adjacent to local communities to prevent easy entry to the property by people or dogs (e.g. constructing electrified game fences or bonnox fences). However, respondents noted that communities will cut fences to allow wildlife to pass through so that they may snare them. Finally, respondents advocated for outreach campaigns in communities to instruct community members about why dog hunting should cease.

\subsection{Taxi hunting}

In total, 22 respondents (44\%) stated that taxi hunting is a severe threat to oribi, with one explaining 'There's hunting by the chap who just lives in the location who has 2 or 3 dogs and just runs around and might catch a buck here or there. Then there's the organized, professional hunting, the taxi hunting, where you've got 150 dogs that will kill 40 buck hunting ... They're going to put a huge strain on your wildlife population, especially your oribi. [The hunters] put a higher value on oribi. The dog which catches the oribi gets more money.' Some respondents believed that taxi hunting has increased in frequency to the point that it may be occurring in the immediate area monthly. Although 5 respondents $(10 \%)$ claimed that taxi hunting does not occur on their property, other respondents refuted this claim. They argued that unless the farmer is alerted to the presence of taxi hunters, there is little evidence that a hunt occurred because the hunts occur on foot in the early hours of the morning. Respondents who considered taxi hunting to be a small or moderate threat stated that their farms are patrolled by security guards, protected by game fences, or are isolated and not easily accessible.

Respondents considered taxi hunting to be a prime example of political and legal corruption, and racial tension in South Africa. According to respondents, the greyhounds that are used for taxi hunting are valuable, highly trained animals, which are owned by businessmen, government officials, and high-ranking members of the legal system and police force. These 
individuals have the necessary wealth to purchase greyhounds, as opposed to local community members who hunt with mixed-breed dogs. Respondents noted that, ideally, hunts must be prevented before greyhounds are unloaded from the taxis. Once the hunt starts, the only way to intervene is to shoot the dogs, which may result in violence (e.g. farmers or staff shot at or wounded by hunters), legal retribution (e.g. police arrest of farmers for shooting greyhounds, legal charges based on claims that farmers threatened or assaulted taxi hunters), property damage (e.g. arson), theft, and intimidation (e.g. verbal threats). Two respondents described the situation thus:

- 'There are threats. They keep warning me that they're coming to hunt with guns, and they'll shoot me. Fine. Let them come. We'll shoot each other.'

- 'It's political. It's all tied in with all our underlying issues in this country. And you've got to be extremely careful now. These guys are extremely well connected. And they won't hesitate to set fires to your farm in revenge. They could attack you. They run to the police extremely quickly. And then they lay counter charges ... and you find you have been charged. And you say 'What am I charged with?' It's always the same things. 'You called me [a racist name]. You pointed a loaded firearm at me. You assaulted me'.'

Provided that farmers do not assault taxi hunters, the courts are likely to dismiss charges by taxi hunters against farmers. However, respondents claimed that the police will not arrest taxi hunters, and courts may not uphold charges by farmers against taxi hunters. As argued by 1 respondent, 'We need back-up. We need police and magistrate courts that are going to come down on this and we need awareness programs ... People need to be told 'it is illegal to hunt over there and if that guy catches you there, he is quite entitled to shoot your dogs' ... [Taxi hunters] come into the police station angrier than we are. And the police support them. They charge us before they charge them. In fact, they never charge them. [The taxi hunters] just walk out. I don't know of anybody who's ever been convicted. Ever. It doesn't happen.' Respondents stated that fear of retribution by taxi hunters is a powerful incentive to take no action to prevent hunts. Some respondents admitted that they had reached the point where they would prefer the oribi to be eradicated from their farms.

Given the dangers of directly engaging with taxi hunters, respondents $(\mathrm{n}=31 ; 62 \%)$ increasingly used security personnel to prevent taxi hunts. Most respondents pay private security companies to protect their families and properties at night. These compa- nies provide protection for agricultural landowners against armed robberies, thefts, livestock theft, illegal hunting, and vandalism. Respondents stated that there is less incidence of retribution if private security companies arrest hunters. Some respondents installed security cameras on the roads surrounding their farms to deter taxi hunting and other crime. Finally, respondents coordinated with other neighboring farmers to stop taxi hunting if a hunt occurs in the area. Regardless of which actions they took to prevent taxi hunting, respondents considered these efforts moderately effective (at best) at protecting oribi.

\subsection{Managing predators}

Owing to farmers' concerns about how blackbacked jackals Canis mesomelas affect livestock operations, respondents tended to consider jackals a threat to oribi, stating, for example, 'We've seen jackal attacking quite mature calves, so if we've seen that I would say young oribi must be under serious pressure.' In total, 16 respondents (32\%) stated that the jackal population decreased during a rabies outbreak, but that the population was starting to recover. In contrast, 11 respondents $(22 \%)$ stated that the jackal population had increased, largely because dairy farms provide jackals with an additional food source in the form of cow placentas. The increase in the jackal population was also attributed to failure by the government to control jackal numbers.

Most respondents $(n=34 ; 68 \%)$ stated that jackals are definitely a threat to oribi, although these individuals differed in their opinions on how severe the threat is. Others stated that jackals are only a threat to young oribi or that they are a natural threat to oribi, since these 2 species have historically coexisted. Respondents' perceptions of the threat that jackals pose to oribi depended on their evaluations of how the jackal population has changed over time. In total, 14 respondents (28\%) considered the serval Leptailurus serval and caracal Caracal caracal to be threats to oribi, yet the threat was considered moderate. Ten respondents $(20 \%)$ were not certain which animals prey on oribi, or whether predators pose a real threat. Eighteen respondents $(36 \%)$ indicated that they shoot jackals, servals, and caracals to protect livestock, although 9 of these respondents also stated that shooting predators benefits the oribi and other wildlife. Some respondents suggested it is better to selectively shoot individuals known to kill livestock and to let a dominant pair of predators establish a territory, provided that they prey on abundant 
wildlife species rather than livestock, oribi, or other endangered wildlife.

\subsection{Habitat loss}

Only 6 respondents $(12 \%)$ considered habitat loss to be an ongoing threat to the oribi, and noted, for example, 'The red grass [Themeda triandra] in the Natal midlands is being threatened, very severely threatened by agriculture, which is a threat to oribi. That's the biggest threat to oribi.' Most respondents stated that although habitat loss was a threat in the past, current stringent rules on the conversion of grasslands to other uses have eliminated that threat. Respondents ( $n=26 ; 52 \%$ ) also argued that the oribi benefit from their farming practices because oribi utilize both improved pasture and unimproved veld for grazing, and they hide in crops such as corn and sugarcane, with 1 respondent explaining, 'There is this story that habitat is the main thing that nails the oribi, which in my opinion is wrong. It is [correct] in the sense that they won't stay in the timber plantations. But they're always in our rye grass, in our [corn] ... And then the pastures. That's why the reedbuck [Redunca arundinum] have increased so much. Because they've got food all year round. Irrigated pastures. And the oribi are also on those irrigated pastures in winter.'

Few respondents $(\mathrm{n}=6 ; 12 \%)$ possessed a clear understanding of the oribi's habitat requirements, while some $(n=8 ; 16 \%)$ noted that they were uncertain how best to manage their lands for the benefit of oribi. Owing to financial constraints and the firm belief that oribi benefit from their current agricultural practices, most respondents did not manage their lands specifically to benefit oribi. However, some respondents $(n=7 ; 14 \%)$ were actively returning their farms to grasslands by removing timber plantations and encroaching bush and protecting wetlands and remnant Themeda grasslands on their farms (sometimes as part of a conservancy). One explained, for example, 'We've gotten rid of the pine [Pinus spp.] and the wattle [Acacia pycnantha] and then we're getting rid of the gum [Eucalyputs spp.]. Oribi are like wattled crane [Bugeranus carunculatus]. They don't like forest.'

Livestock farmers ( $\mathrm{n}=41 ; 82 \%$ ) stated that they tend to understock their farms and they engage in rotational grazing to protect their grassland from overgrazing and related changes in the plant composition of the grassland. They argued that their grazing practices benefit the oribi. While some respon- dents ( $\mathrm{n}=4 ; 8 \%$ ) believed that the oribi will avoid areas where cattle are grazing, others $(n=6 ; 12 \%)$ argued that the oribi are not disturbed by cattle and that they are better protected from illegal hunting and predators when they graze in the same areas as the cattle.

\subsection{Limitations}

There are 2 limitations to the study. First, we assumed that respondents knew what an oribi antelope is. This assumption was reinforced by respondents' accurate descriptions of the appearance and behavior of oribi, but we note that we did not present respondents with a photograph of oribi to confirm their identification of oribi. Second, our research only focused on white farmers in KZN. We did not deliberately exclude black farmers. Neither the Oribi Working Group nor any of our research participants referred us to black farmers, possibly because there are only 4 known black farmers with oribi on their land. Additionally, we did not survey landowners or communities in the Eastern Cape, which also contains oribi and where black communities are predominantly Xhosa, and not Zulu as they are in KZN. More research is required, in particular with black farmers and communities, to understand their perspectives on oribi conservation. Although our findings should not be used to make inferences for all South African farmers, we used the independent parallel coding procedure recommended by Thomas (2006) to ensure validity of analysis.

\section{DISCUSSION}

Understanding landowners' attitudes, perceptions, and limitations is essential to conserving wildlife on private lands, especially when these species are not adequately protected on public lands. Our research adds to nascent research literature on the social aspects of private land conservation in South Africa (see e.g. Selinske et al. 2015, Gooden \& Grenyer 2019, Topp et al. 2021) by investigating landowners' willingness to conserve oribi antelope, which are heavily dependent on remnant grassland habitat on private lands and are under considerable pressure from illegal hunting. We found that private landowners were willing to protect oribi on their lands, which is critical to oribi conservation efforts. Consistent with other research, respondents conserved oribi because conserving wildlife is part of their cul- 
tural heritage and a moral obligation (Hansson et al. 2012, Rubino \& Pienaar 2018), and they wanted to ensure that future generations are able to see wildlife (Hansjürgens et al. 2017). However, some respondents possessed a strong affinity for oribi. They conserved oribi out of an emotional attachment and a sense of pride in maintaining an endangered species on their lands for current and future generations (see Rubino \& Pienaar 2018 for similar findings related to rhino conservation). Many respondents considered oribi to be defenseless against hunting dogs, and experienced illegal oribi hunting as a threat to their cultural identity and a form of cultural victimization (Griffiths 2017). Although some respondents sold live oribi to other landowners as a form of income generation, government permits are required to translocate and legally hunt oribi, which limits revenues that can be earned from oribi (see also Shrader et al. 2016).

Despite their stated commitment to protecting oribi, many respondents were not well informed about biological threats to the species (Shrader et al. 2016). Respondents' belief that jackals are the predator that poses the greatest threat to oribi populations was motivated largely by the threat that jackals pose to livestock (Nattrass et al. 2020). Respondents correctly identified that the jackal population has increased over recent years (Minnie et al. 2016), but the true risk jackals pose to oribi is unknown. Moreover, although habitat loss is widely considered to be one of the greatest risks to oribi in South Africa (Shrader et al. 2016), most respondents did not consider this a threat. Given that an estimated $60 \%$ of South Africa's grasslands have already been converted to other uses (Carbutt \& Martindale 2014, Shrader et al. 2016) and obtaining permits for the conversion of grasslands is a difficult task, it is likely that respondents did not perceive habitat loss to be a threat because grassland conversion has slowed. In fact, respondents considered the conversion of natural grasslands to agriculture as beneficial to oribi because they considered pasture and crops to be higher-quality forage. Although oribi do utilize artificially managed or altered grasslands, such as hayfields, they favor natural grasslands (Shrader et al. 2016). Oribi presence on pastures and in croplands is more likely a result of reduced or degraded natural habitat, rather than a preference for these areas. The fact that respondents generally did not perceive habitat loss to be a threat to oribi is cause for concern because it means they are unlikely to take measures to reestablish or actively manage grasslands.

Contrary to arguments by biologists that snaring is a severe risk to oribi (Shrader et al. 2016), respon- dents considered it a minimal risk that they can mitigate by monitoring their staff and fences (see also Grey-Ross et al. 2010). By contrast, respondents stated that dog hunting, particularly taxi hunting, poses higher risks in terms of threats to the oribi, racial and political conflict, and potential retribution (an assessment that is consistent with Shrader et al. 2016). Given the strong racial and political tensions that underlie illegal hunting of oribi, our findings suggest that respondents' protection of the oribi was motivated by a desire to protect their property, culture, and heritage against crime and corruption in South Africa (Griffiths 2017). Respondents regarded illegal hunting of oribi as a symbol of much larger political and social conflicts in South Africa, including conflicts over land reform and property rights.

Political and social conflicts over wildlife management originate from South Africa's history of racially based land dispossessions during its colonial history and apartheid, which resulted in white people owning large, fertile agricultural lands and controlling access to wildlife (Hübschle 2017, Massé 2019, Spierenburg 2020). Black South Africans were allocated marginal agricultural lands, prohibited from hunting wildlife, typically forced to reside in townships (or 'homelands'), and paid very low wages (Massé 2019, Spierenburg 2020). Black farm 'dwellers' remained on white-owned farms where they were permitted to cultivate some land and graze their livestock in return for agricultural labor (labor tenancy), although farm 'workers' were also paid some wages (Spierenburg 2020).

The first post-apartheid government introduced land reform policies to restore land to dispossessed people to attain more equitable land tenure and land-based economic development in South Africa (Kepe et al. 2001), whilst also deregulating the agrarian sector (elimination of marketing boards, price controls, export monopolies, and subsidies; Spierenburg 2020). Unfortunately, these policies had unintended consequences. They increased farm consolidation and layoffs and evictions of farm laborers and their livestock (which were initially triggered during apartheid due to declining prices for agricultural products and were reinforced by the transition of agricultural land to game ranches; Griffiths 2017, Spierenburg 2020). The introduction of a minimum wage for agricultural workers in 2003, and the passage of the Labor Tenant Act (1996) and the Extension of Security of Tenure Act (1997) to secure occupancy and land use rights for farm dwellers, resulted in further layoffs and evictions of farm laborers (Spierenburg 2020), which in combination with lim- 
ited transfer of land to black South Africans, has exacerbated tensions between white farmers and black communities. The rapid expansion of game ranching reinforced restrictions on hunting by farm dwellers and local communities and the belief in communities that wildlife are valued more highly than black South Africans' lives (Snijders 2012, Spierenburg 2020).

In addition to unresolved disputes over property rights, struggles over wildlife management are underpinned by conflicts between formal and informal institutions, power dynamics through which resource tenures are renegotiated (Kepe et al. 2001, Duffy et al. 2016, Massé 2019), and poverty in local communities. Poverty encompasses both material deprivation and 'lack of power, prestige, voice, and an inability to define one's future and day-to-day activities' (Duffy et al. 2016, p 16). In South Africa, unemployment is high (30.8\% in September 2020), $65.4 \%$ of the population lives below the poverty line, and infrastructure and service delivery in rural areas is poor (Clack \& Minnaar 2018, Leonard 2019). Within this context, community members may view illegal wildlife hunting as both necessary to meet their material needs and a means to affirm their identity, status, customs, and local prestige (Duffy et al. 2016, Hübschle 2017). Local communities argue that they are justified in hunting with dogs on private farmlands and in protected areas because they were deprived of their traditional hunting rights and access to resources by the colonial and apartheid governments (Kepe et al. 2001, Hübschle 2017, Massé 2019, Chambers 2020). Local communities also argue that they hunt smaller wildlife because they have no access to refrigeration, rather than larger, charismatic wildlife (Hübschle 2017) that tend to be valuable in South Africa's game ranching system. Hunting by local communities is thus motivated by subsistence needs, social and cultural tradition, and 'the concept of ukujola, a Zulu term for locally legitimate stealing of a resource based on historical claim to it' (Chambers 2020, p 27).

During apartheid, when ukujola was in direct conflict with government laws and regulations that prevented hunting by black South Africans, traditional authorities (community chiefs, headmen), who were the instruments of the apartheid government (Hübschle 2017, Leonard 2019), assisted in enforcing hunting restrictions (Kepe et al. 2001). However, the rise of civic organizations since the end of apartheid has altered power relations and wildlife use at the local level (Kepe et al. 2001). 'In their attempt to claim authority over the chiefs and headmen ... and to be seen as a legitimate leadership that strives for development and justice, civic organizations have encouraged people to support ukujola as a means to claim rights of access to wildlife, and to lay a claim to land and resources they believe belong to the community' (Kepe et al. 2001, p 917). Unfortunately, multiple decisions by community leaders may indirectly contribute to illegal wildlife hunting by communities by further impoverishing communities. In KZN, collusion between corporate interests (e.g. mining) and government and traditional leaders (who receive personal benefits and/or shares in companies) has adversely affected communities' economic, physical, and social well-being by undermining community participation in decision-making about resource uses (Leonard 2019, see also Hübschle 2017).

Respondents' ranking of the relative threat that illegal hunting poses to oribi from snaring (least concern) to taxi hunting (greatest concern) was correlated with the level of control that they had over that form of hunting and the potential repercussions from intervening to prevent illegal oribi hunting. In common with previous research (Shrader et al. 2016), respondents recognized that taxi hunting is more destructive to wildlife than hunting by small groups from local communities. However, they were also seriously concerned that the individuals who engage in taxi hunts are not hunting for subsistence purposes and may have greater political and legal protection than respondents - concerns that were reinforced by worsening rural crime and political corruption in South Africa. Livestock theft (150 000 to 200000 livestock stolen each year; USD 87 million in value in 2017), illegal wildlife hunting, theft of farm equipment, arson, property damage, and intimidation, robbery, rape, assault, physical injuries, and murder of farmers, farm workers, and their families (average of 60 murders $\mathrm{yr}^{-1}$ from 1996 to 2017) have increased over the past 2 decades in rural South Africa (Clack \& Minnaar 2018). Rural crimes are usually motivated by robbery ( $90 \%$ of cases) rather than political or racial conflicts ( $2 \%$ of cases), and apprehended perpetrators have stated that crimes only turned violent when victims were uncooperative, retaliated or could identify the perpetrators (Clack \& Minnaar 2018). Nonetheless, white farmers feel highly threatened (Clack \& Minnaar 2018) and under siege - a situation that is worsened by rising organized crime in rural areas. Since 2008, livestock theft has been increasingly driven by organized groups that steal entire herds of livestock (usually at night) for slaughter at participating abattoirs (Clack \& Minnaar 2018). Lucrative illegal hunting of wildlife that is organized 
by criminal syndicates, violent, and makes use of impoverished, disenfranchised young men is also well documented in rural South Africa (Hübschle 2017, Massé 2019).

Taxi hunting is part of this trend of organized crime in rural areas but was also clearly associated in respondents' minds with political corruption and 'state capture' in South Africa. State capture is defined as 'actions of individuals or groups both in the public and private sectors, influencing the formation of laws, regulations, decrees and other government policies to their own personal advantage' (Martin \& Solomon 2016, p 22). State capture in South Africa has generated complex patronage networks (at the national and provincial levels) that both redirect fiscal resources away from economic development and public goods provision and manipulate which individuals are placed in key political positions, thereby allowing governance systems and rules to be violated (Martin \& Solomon 2016). Respondents' claims that taxi hunting involves wealthy government and legal officials, who are knowingly violating several laws, is part of the overwhelming problem of state capture in South Africa. It is thus unsurprising that the threat of violence and legal repercussions associated with taxi hunting has reduced some respondents' desire to protect the oribi. Although respondents were using independent, paid security companies to manage these risks, they would benefit from improved police services (Shrader et al. 2016) and legal protection against taxi hunters. A 2003 inquiry by the South African Human Rights Commission found that rural crime was exacerbated by poor and ineffective service delivery by the South African Police Service (Clack \& Minnaar 2018). Rural police stations often have no operational patrol vehicles, staff shortages, limited access to forensic facilities, and less experienced detectives relative to urban regions (Clack \& Minnaar 2018).

There are no easy solutions to conserving the oribi in South Africa. Private landowners require outreach on how to manage their lands for oribi, but economic pressures and lack of government funding has resulted in a loss of government extension services, and political corruption in the form of state capture has undermined trust in government organizations (Martin \& Solomon 2016). Landowners may require financial assistance to engage in oribi conservation, but these programs must be carefully structured to ensure trusted agencies implement the programs, required land management practices are commensurate with landowners' management objectives, monitoring is not overly onerous, and incentives are appropriate (Kreye et al. 2017, Rubino et al. 2018). The racial, social, and political tensions that underpin illegal hunting of oribi are an even greater challenge to address (Shrader et al. 2016, Chambers 2020). Both landowners who are trying to protect oribi because they are endangered and part of their cultural heritage, and local community members who are snaring and hunting oribi for subsistence purposes have strong ethical justifications for their actions. Structural context (the historical, economic, social, and political factors that cause illegal wildlife hunting) must be considered in designing appropriate policy responses to conserve oribi in the long run (Duffy et al. 2016), but we recognize that many required interventions are beyond the purview of a single agency. Interventions are needed that address state capture and corruption (which are negatively affecting both landowners and community members), improve the food and financial security of local communities, and provide communities with a range of choices that enable them to shape their own lives (Duffy et al. 2016, Hübschle 2017, Massé 2019). However, Epanda et al. (2019) have clearly demonstrated that both sustainable livelihoods and positive community attitudes towards wildlife are needed to reduce illegal hunting. Otherwise, community members may invest in illegal hunting by purchasing snares and dogs with their higher incomes (Epanda et al. 2019). Community outreach efforts are likely insufficient to attain positive attitudes towards wildlife. Actively engaging local communities in oribi conservation and providing them with options to purchase game meat at prices they can afford may be more effective options to improve community perceptions of wildlife management and their willingness to protect the oribi. Although increased enforcement is needed to address taxi hunting, this approach is not appropriate for dealing with subsistence hunting by communities because it is likely to further alienate communities and reinforce ukujola (Duffy et al. 2016, Massé 2019).

Acknowledgements. We thank A. Marchant, B. Coverdale, and the other members of the Oribi Working Group for their assistance in the design and implementation of this study. We also thank Dr. Hayward and 3 anonymous reviewers for their comments and suggestions, which greatly improved the quality of this manuscript.

\section{LITERATURE CITED}

Berg BL, Lune H, Lune H (2004) Qualitative research methods for the social sciences, 5th edn. Pearson, Boston, MA Brashares JS, Arcese P (1999) Scent marking in a territorial 
African antelope: I. The maintenance of borders between male oribi. Anim Behav 57:1-10

Bryman A (2001) Social research methods, 5th edn. Oxford University Press, London

Carbutt C, Martindale G (2014) Temperate indigenous grassland gains in South Africa: lessons being learned in a developing country. Parks 20:105-125

* Chambers J (2020) What drives illegal hunting with dogs? Traditional practice in contemporary South Africa. Ethnobiol Lett 11:25-28

Clack W, Minnaar A (2018) Rural crime in South Africa: an exploratory review of 'farm attacks' and stocktheft as the primary crimes in rural areas. Acta Criminol South Afr J Criminol 31:103-135

* Clements HS, Kerley GI, Cumming GS, De Vos A, Cook CN (2019) Privately protected areas provide key opportunities for the regional persistence of large- and mediumsized mammals. J Appl Ecol 56:537-546

Clements HS, Biggs R, Cumming GS (2020) Cross-scale and social-ecological changes constitute main threats to private land conservation in South Africa. J Environ Manage 274:111235

* De Vos A, Clements HS, Biggs D, Cumming GS (2019) The dynamics of proclaimed privately protected areas in South Africa over 83 years. Conserv Lett 12:e12644

Duffy R, St John FA, Büscher B, Brockington D (2016) Toward a new understanding of the links between poverty and illegal wildlife hunting. Conserv Biol 30:14-22

Epanda MA, Fotsing AJM, Bacha T, Frynta D, Lens L, Tchouamo IR, Jef D (2019) Linking local people's perception of wildlife and conservation to livelihood and poaching alleviation: a case study of the Dja biosphere reserve, Cameroon. Acta Oecol 97:42-48

Gooden J, Grenyer R (2019) The psychological appeal of owning private land for conservation. Conserv Biol 33: 339-350

* Grey-Ross R, Downs CT, Kirkman K (2010) An assessment of illegal hunting on farmland in KwaZulu-Natal, South Africa: implications for oribi (Ourebia ourebi) conservation. Afr J Wildl Res 40:43-52

Griffiths M (2017) Heritage lost: the cultural impact of wildlife crime in South Africa. S Afr Crime Q 60:45-50

*Hansjürgens B, Schröter-Schlaack C, Berghöfer A, Lienhoop N (2017) Justifying social values of nature: economic reasoning beyond self-interested preferences. Ecosyst Serv 23:9-17

*Hansson A, Pedersen E, Weisner SE (2012) Landowners' incentives for constructing wetlands in an agricultural area in south Sweden. J Environ Manage 113:271-278

*Hübschle AM (2017) The social economy of rhino poaching: of economic freedom fighters, professional hunters and marginalized local people. Curr Sociol 65:427-447

* IUCN SSC Antelope Specialist Group (2016) Ourebia ourebi. The IUCN Red List of Threatened Species 2016: e.T15 730A50192202. https://dx.doi.org/10.2305/IUCN.UK.20161.RLTS.T15730A50192202.en (accessed 12 Feb 2021)

Kepe T, Cousins B, Turner S (2001) Resource tenure and power relations in community wildlife: the case of Mkambati area, South Africa. Soc Nat Resour 14:911-925

* Kirchherr J, Charles K (2018) Enhancing the sample diversity of snowball samples: recommendations from a research project on anti-dam movements in Southeast Asia. PLOS ONE 13:e0201710

Kreye MM, Pienaar EF, Soto JR, Adams DC (2017) Creating voluntary payment programs: effective program design and ranchers' willingness to conserve Florida panther habitat. Land Econ 93:459-480

Lapeyre R, Laurans Y (2017) Contractual arrangements for financing and managing African protected areas: insights from three case studies. Parks 23:75-88

Keonard L (2019) Traditional leadership, community participation and mining development in South Africa: the case of Fuleni, Saint Lucia, KwaZulu-Natal. Land Use Policy 86:290-298

*Manqele NS, Selier JA, Hill TR, Downs CT (2018) Drivers of the illegal hunting of serval (Leptailurus serval) and oribi (Ourebia ourebi) in the KwaZulu-Natal Midlands, South Africa. Afr J Wildl Res 48:023004

Martin ME, Solomon H (2016) Understanding the phenomenon of 'state capture' in South Africa. South Afr Peace Secur Stud 5:21-35

* Massé F (2019) Anti-poaching's politics of (in)visibility: representing nature and conservation amidst a poaching crisis. Geoforum 98:1-14

Minnie L, Avenant NL, Kamler J, Butler H and others (2016) A conservation assessment of Canis mesomelas. In: Child MF, Roxburgh L, Do Linh San E, Raimondo D, DaviesMostert HT (eds) The Red List of mammals of South Africa, Swaziland and Lesotho. South African National Biodiversity Institute and Endangered Wildlife Trust, Pretoria. https://www.nationalredlist.org/the-red-list-ofmammals-of-south-africa-swaziland-and-lesotho-2016/ (accessed 12 Feb 2021)

* Nattrass N, Drouilly M, O'Riain MJ (2020) Learning from science and history about black-backed jackals Canis mesomelas and their conflict with sheep farmers in South Africa. Mammal Rev 50:101-111

* Pienaar EF, Rubino EC, Saayman M, van der Merwe P (2017) Attaining sustainable use on private game ranching lands in South Africa. Land Use Policy 65:176-185

* Pradhananga AK, Davenport MA, Fulton DC, Maruyama GM, Current D (2017) An integrated moral obligation model for landowner conservation norms. Soc Nat Resour 30:212-227

* Rubino EC, Pienaar EF (2018) Understanding South African private landowner decisions to manage rhinoceroses. Hum Dimens Wildl 23:160-175

Kubino EC, Pienaar EF, Soto JR (2018) Structuring legal trade in rhino horn to incentivize the participation of South African private landowners. Ecol Econ 154:306-316

* Rural Development and Land Reform (2017) Land audit report. Phase II: private land ownership by race, gender and nationality. Republic of South Africa, Pretoria. https:// www.gov.za/sites/default/files/gcis_document/201802/ landauditreport13feb2018.pdf (accessed 12 Feb 2021)

Selinske MJ, Coetzee J, Purnell K, Knight AT (2015) Understanding the motivations, satisfaction, and retention of landowners in private land conservation programs. Conserv Lett 8:282-289

* Shrader AM, Little I, Coverdale B, Patel T (2016) A conservation assessment of Ourebia ourebi. In: Child MF, Roxburgh L, Do Linh San E, Raimondo D, Davies-Mostert HT (eds) The Red List of Mammals of South Africa, Swaziland and Lesotho. South African National Biodiversity Institute \& Endangered Wildlife Trust, Pretoria. https:// www.nationalredlist.org/the-red-list-of-mammals-ofsouth-africa-swaziland-and-lesotho-2016/ (accessed 12 Feb 2021)

Shumba T, De Vos A, Biggs R, Esler KJ, Ament JM, Clements HS (2020) Effectiveness of private land conserva- 
tion areas in maintaining natural land cover and biodiversity intactness. Glob Ecol Conserv 22:e00935

Skinner JD, Chimimba CT (2005) The mammals of the southern African sub-region. Cambridge University Press, Cambridge

Skowno AL, Poole CJ, Raimondo DC, Sink KJ and others (2019) National biodiversity assessment 2018: the status of South Africa's ecosystems and biodiversity. Synthesis report. South African National Biodiversity Institute, Department of Environment, Forestry and Fisheries, Pretoria

Snijders D (2012) Wild property and its boundaries on wildlife policy and rural consequences in South Africa. J Peasant Stud 39:503-520

South African National Biodiversity Institute (2015) Factsheet on biodiversity stewardship, 2nd edn. South African National Biodiversity Institute, Department of Environment, Forestry and Fisheries, Pretoria

Editorial responsibility: Matt Hayward,

Callaghan, New South Wales, Australia

Reviewed by: 3 anonymous referees
Spierenburg M (2020) Living on other people's land; impacts of farm conversions to game farming on farm dwellers' abilities to access land in the Eastern Cape, South Africa. Soc Nat Resour 33:280-299

Stears K, Shrader AM (2015) Increases in food availability can tempt oribi antelope into taking greater risks at both large and small spatial scales. Anim Behav 108:155-164

Taylor WA, Lindsey PA, Nicholson SK, Relton C, DaviesMostert HT (2020) Jobs, game meat and profits: the benefits of wildlife ranching on marginal lands in South Africa. Biol Conserv 245:108561

Thomas DR (2006) A general inductive approach for analyzing qualitative evaluation data. Am J Eval 27:237-246

*Topp EN, Loos J, Martín-López B (2021) Decision-making for nature's contributions to people in the Cape Floristic Region: the role of values, rules and knowledge. Sustain Sci, doi:10.1007/s11625-020-00896-6

Submitted: July 28, 2020

Accepted: February 18, 2021

Proofs received from author(s): May 17, 2021 